\title{
An integrated approach to improving rural livelihoods: examples from India and Bangladesh
}

\author{
Barry Croke ${ }^{1,2}$, Wendy Merritt ${ }^{1}$, Peter Cornish ${ }^{3}$, Geoffrey J. Syme ${ }^{4}$, and Christian H. Roth ${ }^{5}$ \\ ${ }^{1}$ Fenner School of Environment and Society, Australian National University, Canberra, 0200, Australia \\ ${ }^{2}$ Mathematical Sciences Institute, Australian National University, Canberra, 0200, Australia \\ ${ }^{3}$ School of Science and Health, University of Western Sydney, Sydney, 2751, Australia \\ ${ }^{4}$ School of Business and Law, Edith Cowan University, Perth, 6027, Australia \\ ${ }^{5}$ CSIRO Land and Water, Brisbane, 4001, Australia \\ Correspondence: Barry Croke (barry.croke@anu.edu.au)
}

Received: 16 June 2017 - Accepted: 2 August 2017 - Published: 1 February 2018

\begin{abstract}
This paper presents an overview of work in West Bengal, Andhra Pradesh and SW Bangladesh through a series of projects from 2005 to the present, considering the impact of farming systems, water shed development and/or agricultural intensification on livelihoods in selected rural areas of India and Bangladesh. The projects spanned a range of scales spanning from the village scale $\left(\sim 1 \mathrm{~km}^{2}\right)$ to the meso-scale $\left(\sim 100 \mathrm{~km}^{2}\right)$, and considered social as well as biophysical aspects. They focused mainly on the food and water part of the foodwater-energy nexus. These projects were in collaboration with a range of organisations in India and Bangladesh, including NGOs, universities, and government research organisations and departments. The projects were part funded by the Australian Centre for International Agricultural Research, and built on other projects that have been undertaken within the region. An element of each of these projects was to understand how the hydrological cycle could be managed sustainably to improve agricultural systems and livelihoods of marginal groups. As such, they evaluated appropriate technology that is generally not dependent on high-energy inputs (mechanisation). This includes assessing the availability of water, and identifying potential water resources that have not been developed; understanding current agricultural systems and investigating ways of improving water use efficiency; and understanding social dynamics of the affected communities including the potential opportunities and negative impacts of watershed development and agricultural development.
\end{abstract}

\section{Introduction}

Water security for agriculture is a vital component of food security and improving livelihoods. Water security can deliver higher and more stable crop yields, for example through resilience to dry spells in the growing season or it may create new growing seasons, thus intensifying cropping. Improving water security can be achieved across a range of scales. At the village scale (few $\mathrm{km}^{2}$ ), focus can be on improving access to water through rainwater harvesting methods that can be applied by farmers. This can include structures that enable access to shallow groundwater systems (e.g. hand dug pits), small ponds or dams that capture local runoff and the use of deep-rooted perennial plants. A key component of such work is education, including learning about alternative crop options, weed control and fertilizer use, as well as training in managing finances. At meso-scale $\left(\sim 100 \mathrm{~km}^{2}\right)$, options extend to include larger structures that require collaboration across a village or even between villages. These include the use of surface water retention structures (e.g. larger check dams, wells) that provide extended access to surface water and shallow groundwater as well as increasing groundwater recharge. At a larger scale (e.g. basin or state), institutional and governmental drivers become increasingly important.

Underpinning this work (particularly for the higher rainfall in the village scale study area), was the principle that shallow or "renewable" groundwater is the component of groundwater that can be utilized on a sutainable basis (Pavelic et al., 2015). 
The projects discussed here were funded by the Australian Centre for International Agricultural Research (ACIAR). ACIAR invests in research in agricultural landscapes that is intended to deliver positive social, economic and environmental outcomes to a range of beneficiaries, including farmers and rural poor (http://aciar.gov.au/aboutus). Increasingly the agency is funding research projects that move beyond more traditional discipline based research to consider the challenges facing the rural poor and particularly women that prevent them engaging in agricultural activities in a way that meaningfully improves their lives, and to work with communities to identify opportunities into the future.

\section{Village scale}

An Australian-Indian government co-funded project (Cornish et al., 2013, 2015a, b) explored the watershed development (WSD) techniques being used by an NGO (PRADAN) to improve livelihoods in tribal villages in the undulating East India Plateau (EIP). These techniques included structures that individual farmers could implement including dug wells, pits, ponds or small dams to capture rainfall in the wet season and/or tap into shallow, seasonally recharged groundwater resources, and the use of bunds in poor (local) upland areas to retain runoff for high value, perennial crops (e.g. silviculture for silk production; mango orchards). Such work can be done by individual smallholders with or without mechanisation, or collaboratively between farmers across a village. The emphasis was on providing small, mostly privately-owned distributed water resources within a community-developed and owned WSD plan. To supplement this work, PRADAN also trains villagers, particularly women, to manage their finances better. This includes creating women's self-help groups, and encouraging the villagers to pool resources and to lend money amongst themselves. The aim is to improve their natural resources and management practices without incurring unmanageable debt, often accessing funds from a range of government programs.

The village-scale project focused on two villages in the Purulia district of West Bengal, in the foot hills of the EIP. PRADAN had already engaged in one village (Amagara) for a few years and was planning to start work in the second village (Pogro) after the first year of the project, during which socioeconomic and biophysical baselines were established.

\section{Amagara village}

PRADAN had undertaken some WSD in Amagara, but there had been no change in agricultural practices or more effective use of water. Therefore, the focus in this village was on participatory development of new crop options and improved management practices to use water more effectively, and evaluating the agricultural, economic and social effectiveness of the work (Cornish et al., 2015b).

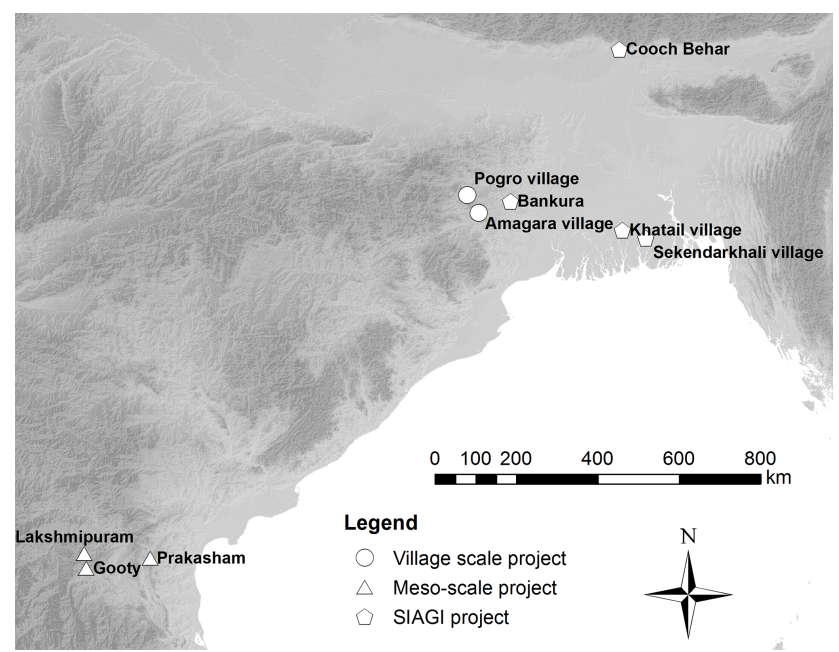

Figure 1. Map showing locations of the study sites for the three projects.

By the end of the project there was clear evidence of village-wide change. Farmers had re-evaluated the worth of "poor" uplands and learnt to use them intensively for vegetables, moved from mono-crop rice to multiple cropping, experimented with different crops to improve their income, and, as a side effect, increase diet diversity (Cornish et al., $2015 b$ ). As a result, seasonal migration was significantly reduced, and there was increased re-investment in improving natural resources, and more was spent on education and medical care. The women reported working harder in the fields, but being more engaged in agricultural decision-making and feeling rewarded in terms of both income and respect. Issues around land leasing agreements and water access arose as the value of uplands for vegetables became clear, along with the value of the water resources created by WSD. These issues impacted most on landless families. One adverse effect of the localized work of PRADAN was that during the project, mango orchards were partially burnt by members from a neighbouring village. While a setback, this lead to discussions between the villages, and reinforced the need to avoid creating potential conflict points that may arise through focused WSD work.

Intensive WSD is expensive, but widely thought to improve agricultural production and livelihoods. However, an important finding from the long-term water balance modelling in this project (Cornish et al., 2015a), combined with participatory experiments (Cornish et al., 2015b), was that comprehensive WSD is not essential in East India (which has relatively high rainfall) to make substantial and more immediate improvements in livelihoods. Much can be done to improve the use of rainfall through a variety of agronomic interventions that reduce rice yield variability and increase cropping intensity and productivity without a commensurate increase in risk. Measures can be taken to use more effec- 
tively existing water resources (pits, ponds and wells) and similar additional low-cost investments more effectively, to develop horticulture on appropriate uplands, convert risky rice-growing land to other crops, and intensify production in the post-monsoon period.

\subsection{Pogro village}

The Pogro village is located within a $2 \mathrm{~km}^{2}$ catchment area (headwater of the Chapai Nula) located near Jaldha and within the Damodar sub-basin of the Lower Ganga Basin. Work here focused on hydrology and agronomy, with a strong social component as in Amagara, involving villagers in experiments and receiving training in the use of fertilizers, weed control and the selection of crops (Cornish et al., 2015b).

Activities in both villages included training villagers to recognize and choose appropriate fertilizers and conducting simple field tests to determine suitable application rates, enabling villagers to observe responses to fertilizers (particularly phosphorous and nitrogen). Villagers also experimented with a range of crop alternatives to rice in trials on all land classes. There was also a gender equity component to the research, focusing on the effectiveness of the self-help groups for women which were created by PRADAN. Ultimately, the effectiveness of the watershed development work hinged on the effectiveness of self-help groups, as these enabled the villagers to develop the capacity to continue development after the end of the project (as observed in Amagara).

\subsubsection{Hydrology}

The Pogro village area was the focus of the hydrological component of this project. The average annual rainfall is approximately $1300 \mathrm{~mm}$, dominated by the southwest monsoon. The outlet of the catchment is defined by a railway culvert, with a small adjoining catchment (approximately $0.5 \mathrm{~km}^{2}$ ) used as a reference. As the culverts were also a thoroughfare for vehicles, people and animals, a v-shaped speed hump design was used (in addition to the culvert structure) as the flow control. An automatic logger was used to monitor water levels in each culvert. An automatic weather station was used to monitor rainfall, temperature, relative humidity wind speed and solar radiation at a 1 min resolution. This was supplemented by manual recording of rainfall, temperature and relative humidity, as well as water levels in ponds, wells and piezometers installed across the catchment (Croke et al., 2008).

The data were used to understand the hydrological response of the study site and evaluate the water balance across the study period (2006-2011), though logged water level data in the culverts were only available from 2009 following permission to install equipment in the railway culvert. This information was used to develop guidelines for the design of watershed development plans, as well as a soil water balance model and micro-catchment scale hydrological model (Cornish et al., 2013, 2015a).

\section{Meso-scale}

Defining the meso-scale to be about $100-200 \mathrm{~km}^{2}$ (or about the size of a Mandal or Block - the second lowest level of Indian government), this project (Syme et al., 2015; Reddy and Syme, 2015) focused more on the social side of the issue of water shed development, while also having a strong focus on the groundwater system. Indian project partners included the Livelihoods and Natural Resources Management Institute, National Geophysical Research Institute, Central Research Institute for Dryland Agriculture, and the International Water Management Institute.

This project had a greater focus on social aspects, with a number of surveys conducted to gain understanding of the attitudes in the study areas, as well as the available resources and limitations. The information collected in these surveys was used to develop a Bayesian network model for each study area (Merritt et al., 2011, 2016).

The study sites were the Vajralavanka-Maruvavanka catchment (approximately $150 \mathrm{~km}^{2}$ ) in the Anantapur and Kurnool districts, and the Peethuruvagu catchment (approximately $100 \mathrm{~km}^{2}$ ) in the Prakasham district in Andhra Pradesh. In comparison to the Pogro study site, the study sites in Andhra Pradesh have a semi-arid climate with an average annual rainfall of approximately $500-700 \mathrm{~mm}$, approximately half that of the study site in West Bengal, with rain from the southwest monsoon being less reliable. As a result, there is a greater reliance on groundwater resources in the area relative to West Bengal.

The micro-catchment scale hydrological model developed in the previous project was used as the starting point for developing a meso-catchment scale model. The primary study sites were not gauged, so the model was developed using data for a nearby gauged site (Lakshmipuram) with a catchment area of approximately $2750 \mathrm{~km}^{2}$ (an order of magnitude larger than the study sites), and the model used to predict the available surface and shallow groundwater water resource in the study sites.

\section{Recommendations from village and meso-scale projects}

Based on the findings in these two projects, a number of recommendations were put forward for future WSD planning and implementation work, as well as policies related to WSD. A selection of these is given here (for more detail see Cornish et al. (2013, 2015a, b), Syme et al. (2015) and Reddy and Syme (2015). 


\subsection{Village-scale project}

- In East India, proven agronomic interventions that reduce risks with rice and increase crop productivity and cropping intensity should be scaled out, especially where there is not the funding or technical capacity to implement WSD.

- Training farmers in basic agriculture and to effectively conduct their own field experiments is vital to ensuring WSD is effective in positively influencing livelihoods, because providing additional water resources alone does not necessarily lead to effective use of those (or existing) water resources. Extension agencies should adopt a flexible approach capable of handling weather/climate changes; and take a participatory approach allowing farmers (including wife) to learn rather than be told.

- Farmers will develop their own adaptive systems, but they need to be equipped to understand their water resources and match these to crop options.

- In the relatively high rainfall area in East India, research should strive towards climate-responsive farming systems with water requirements that broadly match water supply from current rainfall, including water captured in the annually recharged shallow groundwater system as well as local surface runoff, thus minimising dependency on deep groundwater for irrigation.

\subsection{Meso-scale project}

- The present blanket, fixed per unit area allocation of funds to WSD is not appropriate. Rather, allocation needs to be location-specific with funds divided, within and between watersheds depending on agro-climatic and hydrogeological factors.

- It is not necessary for the entire area to be treated. In fact, some portion of the watershed could be left untreated as a buffer (donor) for the rest of the watershed.

- Household resilience is an important indicator of the socio-economic impacts of WSD at all scales, and needs to be explicitly considered.

- Achieving equity remains a difficult issue to be resolved at all scales, and demands judicious planning of interventions with justice principles in mind.

- As competition for land and water increases, at all scales there will need to be improved regulation of agreements that give marginal families access to land and water.

- Bayesian Networks (BNs) have the potential to support integrated watershed management program (IWMP) design and evaluation.
- Stakeholder engagement is an integral part of any research project aiming for policy changes.

- The project has helped to improve the Detailed Project Report (DPR) process - the vehicle by which the IWMP is implemented while there has been some progress in institutional terms understanding process evaluation is still in its early stages.

- Similarly, continued efforts are needed to build capacity within the GOs and NGOs in the implementation of the DPR.

- In terms of the hydrological and biophysical research it is necessary that the impact of these factors is examined in the context of different landscapes, particularly in alluvial river basins such as the Ganges.

\section{Multi-scale climate change adaptation project}

An important consideration for water and food security is the impact of projected climate change, and developing capacity to adapt to such changes. In addition to the aforementioned projects, ACIAR funded a project (the ACCA project) entitled "Developing multi-scale climate change adaptation strategies for farming communities in Cambodia, Lao PDR, Bangladesh and India" (Van Wensveen et al., 2016; Hochman et al., 2017a, b). Using a participatory onfarm research process coupled to modelling, this project developed and tested a range of options to respond to climate risk, centred on strategic irrigation. Farmer capacity to adapt to possible climate change was built through Climate Clubs and village level Climate Information Centres.

\section{Current research: increased emphasis on social research and community engagement}

Drawing on learnings from the all of the above projects, the "Promoting socially inclusive and sustainable agricultural intensification in West Bengal and Bangladesh" project (SIAGI) is a collaborative project involving research and NGO partners from India, Bangladesh, Australia and Wageningen University (https://siagi.org/about-siagi/). It aims to further understand how socially disadvantaged groups, such as landless, marginal smallholders or women-headed household engage with agriculture and to work with these households (and the broader community) to identify and promote opportunities for these households to benefit from agricultural intensification. The project is undertaking integrated research into nutrition sensitive agriculture, value chains and pro-poor markets and social justice and equity issues.

In Bangladesh, SIAGI is working in two villages in two polders in the coastal zone of Bangladesh. In this region, activities such as cropping, livestock rearing and aquaculture are constrained or enhanced by many climatic or environmental factors that vary in time and space: some key drivers 
being soil, groundwater and surface water salinity in the rabi season (in particular), with associated freshwater shortages for agriculture and consumption, and drainage and waterlogging issues during and at the end of the monsoon. Salinity and a lack of available water currently contribute to much of the land being fallow in the dry season. The biophysical conditions in the polders are influenced to a considerable extent by the maintenance and management of polders and the irrigation infrastructure (canals and sluice gates). Social processes around who uses the water, for what, and when (and the equity of decisions made within a community) are a key focus of SIAGI. SIAGI is partnering with the "Cropping system intensification in the salt-affected coastal zones of Bangladesh and West Bengal, India" project, which is undertaking soil, water and crop research in the same study villages as well as investigating polder-scale water and salt management strategies (http://aciar.gov.au/project/lwr/2014/ 073).

\section{Conclusions}

Water and food security are vital for improving livelihoods in disadvantaged rural areas. Hydrological understanding is central to the design of watershed development works intended to improve water security. However, whether new water resources are made available through WSD or not, it is important to address the design and management of farming systems to ensure water is used productively and sustainably. It is also vital for social constraints and equity to be considered. Finally, a participatory learning approach is useful for ensuring that any watershed development work is effective in producing long-term improvement in livelihoods.

Data availability. The dataset for the village scale project is publicly available.

Competing interests. The authors declare that they have no conflict of interest.

Special issue statement. This article is part of the special issue "Water security and the food-water-energy nexus: drivers, responses and feedbacks at local to global scales". It is a result of the IAHS Scientific Assembly 2017, Port Elizabeth, South Africa, 10-14 July 2017.

Acknowledgements. The authors acknowledge funding from the Australian Centre for International Agricultural Research for projects: Water harvesting and better cropping systems for smallholders of the East India Plateau (LWR/2002/100), Impacts of meso-scale Watershed Development (WSD) in Andhra Pradesh (India) and their implications for designing and implementing improved WSD policies and programs (LWR/2006/072), and
Promoting socially inclusive and sustainable agricultural intensification in West Bengal and Bangladesh (LWR/2014/072).

Edited by: Graham Jewitt

Reviewed by: Nadja den Besten and one anonymous referee

\section{References}

Cornish, P., Croke, B., Kumar, S., and Karmakar, D.: Water harvesting and better cropping systems for smallholders of the East India Plateau, Final report for LWR/2002/100, available at: http: //aciar.gov.au/publication/FR2013-25 (last access: 15 September 2017), 2013.

Cornish, P. S., Choudhury, A., Kumar, A., Das, S., Kumbakhar, K., Norrish, S., and Kumar, S.: Improving crop production for food security and improved livelihoods on the East India Plateau II, Crop options, alternative cropping systems and capacity building, Agr. Syst., 137, 180-190, https://doi.org/10.1016/j.agsy.2015.02.011, 2015a.

Cornish, P. S., Karmakar, D., Kumar, A., Das, S., and Croke, B.: Improving crop production for food security and improved livelihoods on the East India Plateau. I, Rainfall-related risks with rice and opportunities for improved cropping systems, Agricultural Systems, 137, 166-179, https://doi.org/10.1016/j.agsy.2015.01.008, 2015b.

Croke, B., Norrish, N., Kumar, A., Islam, A., Dey, P., Cornish, P., Kumar, S., Ghosh, J., Insights into catchment behaviour for water harvesting assessment in the East India Plateau, in: Proceedings of the iEMSs Fourth Biennial Meeting: International Congress on Environmental Modelling and Software (iEMSs 2008), edited by: Sànchez-Marrè, M., Béjar, J., Comas, J., Rizzoli, A. E., and Guariso, G., International Environmental Modelling and Software Society, Barcelona, Catalonia, July 2008, 1, 454-461, 2008.

Croke, B., Islam, A., and Cornish, P.: Hydrological data for Pogro study site, Purulia district, West Bengal, India, HydroShare, https://doi.org/10.4211/hs.8e0ad0e45df44404b0ad42ecc84a95da, 2017.

Hochman, Z., Horan, H., Reddy, D. R., Sreenivas, G., Tallapragada, C., Adusumilli, R., Gaydon, D., Kokic, P., Singh, K. K., and Roth, C. H.: Smallholder farmers managing climate risk in India: 1. adapting to a variable climate, Agr. Syst., 150, 54-66, 2017a.

Hochman, Z., Horan, H., Reddy, D. R., Sreenivas, G., Tallapragada, C., Adusumilli, R., Gaydon, D., Laing, A., Kokic, P., Singh, K. K., and Roth, C. H.: Smallholder farmers managing climate risk in India: 2. is it climate-smart?, Agr. Syst., 151, 61-72, $2017 \mathrm{~b}$.

Merritt, W. S., Reddy, V. R., Rao, K. V., Pavelic, P., Ahmed, S., Ranjan, R., Croke, B. F. W., and Syme, G. J.: Integrated modelling for understanding watershed development impacts on social and biophysical systems, in: 19th International Congress on Modelling and Simulation (MODSIM), edited by: Chan, F., Marinova, D., and Anderssen, R. S., 2887-2893, 12-16 December 2011, Perth, Australia, available at: http://mssanz.org.au/ modsim2011/G3/merritt.pdf, 2011.

Merritt, W. S., Patch, B., Reddy, V. R., and Syme, G.: Modelling livelihoods and household resilience to droughts using Bayesian networks, Environ. Dev. Sustain., 18, 315-346, https://doi.org/10.1007/s10668-015-9650-1, 2016. 
Pavelic, P., Senaratna Sellamuttu, S., Johnston, R., McCartney, M., Sotoukee, T., Balasubramanya, S., Suhardiman, D., Lacombe, G., Douangsavanh, S., Joffre, O., Latt, K., Zan, A. K., Thein, K., Myint, A., Cho, C., and Htut, Y. T.: Integrated assessment of groundwater use for improving livelihoods in the dry zone of Myanmar, Colombo, Sri Lanka: International Water Management Institute (IWMI), IWMI Research Report 164, 47 pp., https://doi.org/10.5337/2015.216, 2015.

Syme, G. J., Reddy, V. R., Pavelic, P., Croke, B., and Ranjan, R.: Confronting scale in watershed development in India, Hydrogeol. J., 20, 985-993, https://doi.org/10.1007/s10040-011-08240, 2012.

Syme, G., Reddy, V. R., Ahmed, S., Rao, K. V., Pavelic, P., Croke, B., Merritt, W., Ranjan, R., Tallapragada, C., Sreedevi, P. D., Sarah, S., Nallan, S., Rout, S., Guillaume, J., and Bernet, D.: Impacts of meso-scale Watershed Development (WSD) in Andhra Pradesh (India) and their implications for designing and implementing improved WSD policies and programs, Final report for LWR/2006/072, available at: http://aciar.gov.au/publication/ fr2015-05 (last access: 15 September 2017), 2015.
Reddy, V. R. and Syme, G. J.: Integrated Assessment of Scale Impacts of Watershed Intervention: Assessing Hydrogeological and Bio-physical Influences on Livelihoods, Elsevier, Amsterdam, 420 pp., 2015.

Van Wensveen, M., Williams, L. M., and Roth, C. H.: Developing multi-scale adaptation strategies for farming communities in Cambodia, Laos, Bangladesh, India. ACIAR Final Report for LWR/2008/019, available at: http://aciar.gov.au/publication/ fr2016-10 (last access: 15 September 2017), 2016. 